for lumbar disc herniation: causes and treatment options". Int Orthop. 2019 Apr;43(4):969-73.

9. Wassenaar M, Van Rijn RM, Van Tulder MW, Verhagen AP, van der Windt DAWM, Koes BW, et al (2012), "Magnetic resonance imaging for diagnosing lumbar spinal pathology in adult patients with low back pain or sciatica: a diagnostic systematic review". Eur spine J Off Publ Eur Spine Soc Eur Spinal Deform Soc Eur Sect Cerv Spine Res Soc. 2012 Feb;21(2):220-7.

\title{
RỐI LOAN NHIPP TIM TRÊN HOLTER ĐIÊN TÂM ĐỒ 24 GIỜ Ở BỆNH NHÂN SUY THẬN ĐƯợC LỌC MÁU CHU KỲ TẠI BỆNH VIỆN BẠCH MAI
}

\author{
Sat Chanthy ${ }^{1}$, Trần Song Giang ${ }^{2}$, Nguyễn Hữu Dũng ${ }^{3}$
}

\section{TÓM TẮT}

Đă̆t vấn đề: Lọc máu chu kỳ ngày càng phổ biến do sổ lượng bệnh nhân suy thận tăng nhanh; tuy nhiên có nhiêu tai biến đặc biệt liền quan đến tî lệ rối loạn nhịp cao. Muc tiêu: Mô tả đặc điểm rối loạn nhịp tim và một số yếu tố liên quan ở bệnh nhân sưy thận được lọc máu chu kỳ tại bệnh viện Bạch Mai. Đối tượng \& phương pháp: 51 bệnh nhân suy thận đang loc máu tại bệnh viện Bạch Mai và không mắc bênh cấp tính. Kết quả: Tuổi trung bình là $54,4 \pm 12,7$ tuổi; tỉ lệ nữ cao hớn so với nam giới (58,8\% so với $41,2 \%)$; phần lớn có thời gian lọc máu 5-10 năm $(35,3 \%)$ và trên 10 năm $(35,3 \%)$. Tỉ lê rối loan nhip tim trên holter điện tâm đồ 24 giờ $(80,4 \%)$ : rối loạn nhip trên thất (NTi nhĩ đơn lẻ: $41,2 \%$; NTTnhĩ chùm đôi: 15,7\%, nhịp nhanh xoang $\geq 50 \%$ : 3,9\%, nhịp nhanh kịch phát trên thất: $5,8 \%$, cơn rung nhĩ: $9,8 \%$ ); rối loạn nhịp thất (NTT thất nhịp đôi: 11,8\%, nhịp ba: $7,8 \%$, đa dang, phức tap: $7,8 \%$, chùm đôi, chùm ba: 5,9\%, dạng R/T: 3,9\%, cơn nhịp nhanh thất không bền bỉ: $6,9 \%$ ). Tỉ lệ rối loan nhịp cao hơn ở nhóm có THA, ĐTĐ, thiếu máu. Kết luận: Tỉ lệ rối loạn nhịp cao ở bệnh nhân lọc máu chú kỳ có liên quan đển tăng huyết áp, thiếu máu và rối loạn điện giải.

Tư khóa: bệnh thận mạn, lọc máu chu kỳ, rối loạn nhịp, holter điện tâm đồ.

\section{SUMMARY}

ARRHYTHMIA IN HOLTER 24 HOUR IN END STAGE RENAL DISEASE PATIENTS ON HEMODIALYSISAT BACH MAI HOSPITAL

Background: Hemodialysis is popular of patients with renal failure; however, many adverse events are particularly associated with high rates of arrhythmias. Objectives: To describe the characteristics of heart rhythm disturbances and some related factors in renal failure patients undergoing dialysis at Bach Mai hospital. Subjects \& methods: 51 patients with

\footnotetext{
${ }^{1}$ Trường Đại học Y Hà Nội,

${ }^{2}$ Viên Tim mạch Việt Nam - bênh viện Bach Mai,

${ }^{3}$ Trung tâm Thận tiết niệu và lọc máu - bệnh viện Bach Mai.

Chịu trách nhiệm chính: Sat Chanthy

Email: chanthysat15@gmail.com

Ngày nhận bài: 16.9.2021

Ngày phản biện khoa học: 12.11.2021

Ngày duyệt bài: 22.11.2021
}

renal failure undergoing dialysis at Bach Mai hospital. Bach Mai hospital and did not have an acute desease. Results: Mean age was $54.4 \pm 12.7$ years old; the proportion of women is higher than that of men $(58.8 \%$ versus $41.2 \%)$; most had dialysis $5-10$ years $(35.3 \%)$ and more than 10 years $(35.3 \%)$. The rate of arrhythmias on the 24-hour Holter EKG (80.4\%): supraventricular arrhythmias (single atrial ventricular tachycardia: 41.2\%; double cluster atrial ventricular tachycardia: $15.7 \%$, sinus tachycardia $\geq$ ) $50 \%: 3.9 \%$, paroxysmal supraventricular tachycardia: $5.8 \%$, atrial fibrillation: 9.8\%); ventricular arrhythmias (doubleventricular ventricular rate: $11.8 \%$, tripartite: $7.8 \%$, varied, complex: $7.8 \%$, double beam, triple beam: $5.9 \%$, R/T pattern: $3.9 \%$, unstable ventricular tachycardia: $6.9 \%$ ). The rate of arrhythmia is higher in the group with hypertension, diabetes, anemia. Conclusions: The high rate of arrhythmias in patients on hemodialysis is related to hypertension, anemia and electrolyte disturbances.

Keywords: chronic kidney disease, hemodialysis, arrhythmia, holter 24 hour

\section{I. ĐĂT VẤN ĐỀ}

Tại Việt Nam, ước tính có khoảng gần 6 triệu người dân đang mắc bệnh thận (chiếm 6,73\% dân số), trong đó 80.000 người chuyển sang giai đoạn cuối cần điều trị thay thế thận. Trong đó, lọc máu chu kỳ là phương pháp hiệu quả điều trị thay thế thận; tuy nhiên, có nguy cơ gây ra nhiều tai biến, đặc biệt các tai biến về tim mạch.

Rối loạn nhịp là rối loạn thường gặp trên bệnh nhân lọc máu chu kỳ. Tỷ lệ rối loạn nhịp từ $9 \%$ đến $21 \%$ ở bệnh nhân bệnh thận mạn và tăng tới $13 \%$ đến $27 \%$ ở bệnh nhân lọc máu chu kỳ․ Nghiên cứu của tác giả Hoàng Viết Thắng ${ }^{2}$ năm 2010 trên 31 bệnh nhân loc máu chu kỳ được theo dõi trên holter điên tim cho thây có 38,7\% bệnh nhân có nhịp chậm xoang, 80,6\% nhịp nhanh xoang, $12,9 \%$ nhịp nhanh trên thất, 9,7\% nhịp nhanh thất.

Rối loạn nhịp trên bệnh nhân lọc máu chu kỳ có liên quan đến tăng nguy cơ tử vong trên nhóm bệnh nhân này. Đặc biệt, có đến $25 \%$ bệnh nhân lọc máu đột tử, trong đó có $26,9 \%$ được cho là có liên quan đến rối loạn nhịp ${ }^{3}$. Vì vậy, cần được chẩn đoán và điều trị kịp thời. Tuy 
nhiên, phương pháp điên tâm đồ bề mặt 12 chuyển đạo khó có thể đánh giá các rối loạn nhịp mang tính chất cớn hoặc có tính chất chu kỳ. Chúng tôi thực hiện nghiên cứu này nhằm đánh giá tính trạng rối loạn nhịp ở bệnh nhân lọc máu chu kỳ qua holter điện tâm đồ 24 giờ nhằm cung cấp thông tin cho các bác sĩ lâm sàng trong quá trình chẩn đoán và điều trị bệnh với mục tiêu: Mô tả đặc điểm rối loạn nhịp tim và một số yếu tố liên quan ở bệnh nhân suy thận được lọc máu chu kỳ tại bệnh viện Bạch Mai.

\section{II. ĐỐI TƯỢNG VÀ PHƯƠNG PHÁP NGHIÊN CỨU}

Nghiên cứu mô tả trên 51 bệnh nhân, được thực hiện tại trung tâmThận tiết niệu và lọc máuvà viên Tim mach bệnh viện Bạch Mai từ tháng 8/2020-7/2021.

Chúng tôi lựa chọn vào nghiên cứu bệnh nhân từ 18 tuổi trở lên có bệnh thận mạn được lọc máu chu kỳ tại bênh viện Bach Mai. Loại trừ khỏi nghiên cứu những bênh nhân đang sử dung máy tạo nhịp tạm thời hoặc vĩnh viễn, bệnh nhân đang mắc các bệnh cấp tính (suy hô hấp, viêm phổi, viêm cơ tim, nhồi máu cơ tim, nhiễm khuẩn tiết niêuu.

Tất cảbệnh nhân được hỏi bệnh, khám lâm sàng, cận lẩm sàng và ghi holter điện tim 24 giờ tại bệnh viện Bạch Mai nhằm thu thập các thông tin: đặc điểm chung (tuổi, giới, nguyên nhân bệnh thận mạn, thời gian lọc máu, bệnh kèm theo), đặc điểm cận lâm sàng trước lọc máu (hemoglobin, ure, creatin huyết thanh, natri máu, kali máu, canxi máu), đặc điểm holter điện tim 24 giờ (tần số trung bình, tối thiểu, tối đa, các rối loạn nhịp).

Tiêu chuẩn đánh giá trên Holter điện tim 24 giờ theo Remipillier:

- Ngưng xoang: Khi ngủ, ở người trẻ thường có khoảng ngừng tim ngắn, bình thường không vượt quá 2 giây với người > 30 tuổi, không vượt quá 2,5 giây ở người $<30$ tuổi.

- Nhịp nhanh xoang: Nhịp tim có tần số > 100 lần/phút, lớn hơn $50 \%$ tổng nhịp tim.

- Nhịp chậm xoang: Nhịp tim có tần số < 60 lần/phút, lớn hơn $50 \%$ tổng nhịp tim.

- Ngoại tâm thu nhĩ: Giới hạn trên của bình thường là:

$+<10$ ngoại tâm thu nhĩ /24h đối với người $20-39$ tuổi.

+ < 100 NTT nhĩ /24 giờ đối với người 40 59 tuổi.

$+<1000$ NTT nhĩ /24 giờ đối với người $\geq 60$ tuổi.

- Ngoại tâm thu thất: Các dạng NTTT bao gồm NTTT đơn dạng, cặp đôi, cặp ba, NTTT nhịp đôi, nhịp ba và hiện thượng R/T... Giới hạn trên của bình thường là:

+ Ở người < 50 tuổi: < 100 NTTT /24 giờ, < hai ổ NTT, không có NTTT đi liền nhau.

+ Ở người $\geq 50$ tuổi: < 200 NTTT / 24 giờ, có < 2 NTT liên tục và < 5 NTTT / 1 giờ.

- Cơn nhịp nhanh trên thất: Khi có > 3 NTT trên thất đi liền nhau

- Cơn nhịp nhanh thất: Khi có > 3 NTTT đi liền nhau

\section{KẾT QUẢ NGHIÊN CỨU}

Nghiên cứu trên 51 bênh nhân lọc máu chu kỳ tại bênh viên Bach Mai có tuổi trung bình là $54,4 \pm 12,7$ tuổi; tỉ lệ nữ cao hơn so với nam giới (58,8\% so với $41,2 \%)$; phần lớn có thời gian lọc máu $5-10$ năm $(35,3 \%)$ và trên 10 năm $(35,3 \%)$.

\subsection{Rối loạn nhịp của bệnh nhân nghiên} cứu

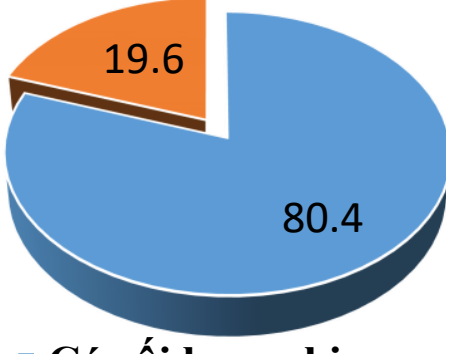

Hình1. Tỉ lệ rôi loạn nhịp chung cưa nhóm nghiên cứu

Nhân xét: Trong nghiên cứu có 41 bênh nhân rối loạn nhịp tim trên holter điện tâm đồ 24 giờ chiếm tỉ lệ 80,4\%.

3.2. Phân bố các rối loạn nhịp trên thất Bảng 1. Tỉ lệ rối loạn nhịp trên thất

\begin{tabular}{|c|c|c|c|}
\hline \multicolumn{2}{|c|}{ Rối loạn nhịp } & $\begin{array}{l}\text { Số lượng } \\
\text { (n) }\end{array}$ & $\begin{array}{l}\text { Tỉ lề } \\
(\%)\end{array}$ \\
\hline \multicolumn{2}{|c|}{ NTT nhĩ đơn lẻ } & 21 & 41,2 \\
\hline \multicolumn{2}{|c|}{ NTT nhĩ chùm đôi } & 8 & 15,7 \\
\hline \multirow{2}{*}{$\begin{array}{c}\text { Nhịp } \\
\text { nhanh } \\
\text { xoang }\end{array}$} & $<50 \%$ & 38 & 74,5 \\
\hline & $\geq 50 \%$ & 2 & 3,9 \\
\hline \multicolumn{2}{|c|}{$\begin{array}{c}\text { Nhịp nhanh kịch phát } \\
\text { trên thất }\end{array}$} & 3 & 5,8 \\
\hline \multicolumn{2}{|c|}{ Cơn rung nhĩ } & 5 & 9,8 \\
\hline \multirow{3}{*}{$\begin{array}{l}\text { Ngưng } \\
\text { xoang }\end{array}$} & Ngắn & 3 & 5,8 \\
\hline & Kéo dài & 1 & 1,9 \\
\hline & 1 xoang & 5 & 9,8 \\
\hline
\end{tabular}

Nhận xét: Ngoại tâm thu nhĩ đơn lẻ là rối loạn nhịp nhĩ thường gặp nhất (41,2\%); ngoại tâm thu nhĩ chùm đôi có tỉ lệ thấp hơn $(15,7 \%)$. Nhịp nhanh xoang có ở 40/51 bệnh nhân, tuy nhiên chỉ có 2 bệnh nhân có thời gian nhịp 
nhanh xoang $\geq 50 \%$ (3,9\%). Tỉ lệ nhịp nhanh kịch phát trên thất $(5,8 \%)$ và có 5 bệnh nhân có cơn rung nhĩ $(9,8 \%)$.

3.3. Các rối loạn nhịp thất

Bảng 2. Tỉ lệ rôi loạn nhịp thất

\begin{tabular}{|c|c|c|c|}
\hline & Chỉ sô & $\begin{array}{l}\text { Số lượng } \\
\text { (n) }\end{array}$ & $\begin{array}{l}\text { Tỉ lệ } \\
(\%)\end{array}$ \\
\hline \multicolumn{2}{|c|}{$\begin{array}{l}\text { Số lượng NTT thất } \\
\text { (nhát/24 giờ) }\end{array}$} & \multicolumn{2}{|c|}{$1812,5 \pm 3112,6$} \\
\hline \multirow{4}{*}{$\begin{array}{l}\text { NTT } \\
\text { thất }\end{array}$} & Nhịp đôi, nhịp ba & 10 & 19,6 \\
\hline & Đa dạng, phức tạp & 4 & 7,8 \\
\hline & Chùm đôi, chùm ba & 3 & 5,9 \\
\hline & $\mathrm{R} / \mathrm{T}$ & 2 & 3,9 \\
\hline
\end{tabular}

\begin{tabular}{|c|c|c|}
\hline $\begin{array}{c}\text { Cơn nhịp nhanh thất không } \\
\text { bền bì }\end{array}$ & 3 & 6,9 \\
\hline Cơn nhịp nhanh thất bền bỉ & 0 & 0 \\
\hline
\end{tabular}

Nhân xét: Số lượng ngoai tâm thu thất trung bình là $1812,5 \pm 3112,6$ nhát/24 giờ. Có $37,3 \%$ số bệnh nhân trong nghiên cứu có ngoại tâm thu thất ở các mức độ khác nhau. Có 3 bênh nhân có cơn nhịp nhanh thất không bền bỉ (6,9\%).Các dạng ngoại tâm thu thất gặp trên Holter điện tim 24 giờ ở bệnh nhân nghiên cứu gồm nhịp đôi $(11,8 \%)$, nhịp ba $(7,8 \%)$, đa dạng, phức tạp $(7,8 \%)$, chùm đôi, chùm ba $(5,9 \%)$ dạng $R / T$ $(3,9 \%)$.

Bảng 3. Liên quan đến rôii loạn nhịp ở bệnh nhân trong nghiên cứu

\begin{tabular}{|c|c|c|c|}
\hline \multirow{2}{*}{\multicolumn{2}{|c|}{ Yêu tố liên quan }} & \multicolumn{2}{|c|}{ Nhóm nghiên cứu } \\
\hline & & Có rối loạn nhịp & Không rối loạn nhịp \\
\hline \multirow{2}{*}{ Tuổi } & $<60$ tuối & $16(80,0 \%)$ & $4(20,0 \%)$ \\
\hline & $\geq 60$ tuối & $25(80,6 \%)$ & $6(19,4 \%)$ \\
\hline \multirow{2}{*}{ Giới } & Nam & $18(85,7 \%)$ & $3(14,3 \%)$ \\
\hline & Nữ & $23(76,7 \%)$ & $7(23,3 \%)$ \\
\hline \multirow{2}{*}{$\begin{array}{c}\text { Thời gian lọc } \\
\text { máu }\end{array}$} & $<5$ năm & $12(80,0 \%)$ & $3(20,0 \%)$ \\
\hline & $\geq 5$ năm & $29(80,6 \%)$ & $7(19,4 \%)$ \\
\hline \multirow{2}{*}{ THA } & Có & $34(79,1 \%)$ & $9(20,9 \%)$ \\
\hline & Không & $7(87,5 \%)$ & $1(12,5 \%)$ \\
\hline \multirow{2}{*}{ Đái tháo đường } & Có & $12(75,0 \%)$ & $4(25,0 \%)$ \\
\hline & Không & $29(82,9 \%)$ & $6(17,1 \%)$ \\
\hline \multirow{2}{*}{ Thiếu máu } & Không & $5(71,4 \%)$ & $2(28,6 \%)$ \\
\hline & Có & $36(81,8 \%)$ & $8(18,4 \%)$ \\
\hline \multirow{2}{*}{$\begin{array}{c}\text { Nông độ Natri } \\
\text { máu }\end{array}$} & $<135$ & $7(63,6 \%)$ & $4(36,4 \%)$ \\
\hline & $\geq 135$ & $34(87,2 \%)$ & $5(12,8 \%)$ \\
\hline \multirow{3}{*}{ Nông độ kali } & $<3,5$ & $6(66,7 \%)$ & $3(33,3 \%)$ \\
\hline & $3,5-4,5$ & $26(89,7 \%)$ & $3(10,3 \%)$ \\
\hline & $>4,5$ & $9(69,2 \%)$ & $4(30,8 \%)$ \\
\hline \multirow{2}{*}{$\begin{array}{c}\text { Nông độ canxi } \\
\text { toàn phân }\end{array}$} & $<2,2$ & $8(61,5 \%)$ & $5(38,5 \%)$ \\
\hline & $\geq 2,2$ & $33(86,8 \%)$ & $5(13,2 \%)$ \\
\hline
\end{tabular}

Nhận xét: Tỉ lệ rối loạn nhịp cao hơn ở nhóm bệnh nhân THA hoặc ĐTĐ typ 2, thiếu máu, hạ natri máu trước lọc, nhưng cao hơn ở nhóm có kali máu hoặc calci máu trước lọc bình thường.

\section{BÀN LUẬN}

Bệnh nhân bệnh thận mạn tính có nguy cơ rối loạn nhịp tim cao; tỷ lệ rối loạn nhịp từ $9 \%$ đến $21 \%$ ở bệnh nhân bệnh thận mạn và tăng tới $13 \%$ đến $27 \%$ ở bệnh nhân lọc máu chu kỳ ${ }^{1}$. Một nghiên cứu năm 1995 trển 258605 bệnh nhân tại thời điểm bắt đầu lọc máu cho thấy tỉ lệ rối loạn nhịp là 11,3\% đến năm 2007 tăng lên 14,3\% ${ }^{4}$. Một phân tích khác năm 2012 trên 25 nghiên cứu cho thấy tỉ lệ rối loạn nhịp chung trên bệnh nhân lọc máu chu kỳ là $11,6 \% 5$. Tuy nhiên, các nghiên cứu trên, chẩn đoán rối loạn nhịp chỉ được thực hiện trên điện tâm đồ bề mặt tại một thời điểm nhất định vì vậy khó có thể đánh giá đúng được tình trạng rối loạn nhịp ở bệnh nhân suy thận lọc máu, đặc biệt những thay đổi trong quá trình lọc máu.
Holter điện tim là một kỹ thuật thăm dò tim không xâm nhập, ghi lại hoạt động điện của tim trong suốt 24 giờ và rất có giá trị trong việc phát hiện RLN tim và đặc biệt là các NTT thất. Trong nghiên cứu của chúng tôi holter điện tâm đồ 24 giời được sử dụng để đánh giá rối loạn nhịp ở bệnh nhân suy thận lọc máu. Kết quả cho thấy có 41 bệnh nhân rối loạn nhịp tim $(80,4 \%)$ trên holter điện tâm đồ. Kết quả nghiên cứu của chúng tôi cho thấy tỉ lệ rối loạn nhịp cao hơn so với các nghiên cứu về rối loạn nhịp trên quần thể dân số chung. Điều này là hợp lý bởi khi tổn thương thận tổn thương rối loạn nhịp cao hơn cả về tỷ lệ và mức độ nhiều các NTT, chứng tỏ rối loạn hệ thần kinh tự chủ nặng nề hơn. Sử dụng ghi điện tim bằng Holter điện tim 24 giờ các các nhóm đối tượng nghiên cứu cho chúng tôi một 
kết quả chính xác về rối loạn nhịp trong 24 giờ. Rất nhiều tác giả đã khẳng định ưu thế của phương pháp này trong chẩn đoán các rối loạn nhịp cho bệnh nhân ${ }^{6-9}$.

Các dạng rối loạn nhịp nhĩ trong nghiên cứu của chúng tôi gồm ngoại tâm thu nhĩ đơn lẻ là rối loạn nhịp nhĩ thường gặp nhất $(41,2 \%)$, ngoai tâm thu nhĩ chùm đôi có tỉ lê thấp hơn (15,7\%); các rối loạn nhịp nhanh ở bệnh nhân trong nghiên cứu gồm nhịp nhanh kịch phát trên thất $(5,8 \%)$; cơn rung nhĩ $(9,8 \%)$; nhịp chậm xoang $(9,8 \%)$. Tuy các rối loạn nhịp nhĩ trong nghiên cứu của chúng tôi có tỉ lệ cao nhưng phần lớn là các cớn ngắn và rối loạn nhịp đơn lẻ, ít có ý nghĩa trong lâm sàng.

Kết quả nghiên cứu của chúng tôi cho thấy số lượng ngoại tâm thu thất trung bình là 1812,5 \pm 3112,6 nhát/24 giờ; trong nghiên cứu có $37,3 \%$ số bệnh nhân trong nghiên cứu có ngoại tâm thu thất ở các mức độ khác nhau; trong đó các dạng ngoại tâm thu thất gặp trên Holter điện tim 24 giờ gồm nhịp đôi $(11,8 \%)$, nhịp ba $(7,8 \%)$, đa dạng, phức tạp $(7,8 \%)$, chùm đôi, chùm ba $(5,9 \%)$ dạng $R / T(3,9 \%)$. Kết quả liên quan đến tỉ lệ THA cao ở nhóm bệnh nhân lọc máu chu kỳ và các yếu tố khác như thiếu máu, qua trình lọc máu tạo áp lực lên hệ thống tim mạch gây tổn thương tâm thất nhiều hơn. Kết quả của chúng tôi cũng phù hợp với các kết quả nghiên cứu trong và ngoài nước. Trong nghiên cứu của tác giả Nguyễn Tá Đông đã chỉ ra nhóm bệnh nhân có tổn thương thận có tỷ lệ rối loạn nhịp tim cao hơn nhóm chưa có tổn thương thận $(57,8 \%$ so với 26,4\%).

Tuy nhiên, kết quả nghiên cứu của chúng tôi không thấy liên quan giữa tuổi và giới với tình trạng rối loạn nhịp ở bệnh nhân trong nghiên cứu. Chúng tôi cho rằng kết quả này hợp lý bởi nhóm nam và nữ của chúng tôi tuổi đều khoảng hơn 60 tuổi, nhóm bệnh nhân nam có nhiều yếu tố nguy cơ hơn nữ nển mức độ và tần suất tổn thương thần kinh tự chủ nhiều hơnn. Cũng như, tuổi cao sẽ có những rối loạn nhịp do thoái hóa cơ tim và phù hợp sinh lý tuổi già và đặc biệt ở bệnh nhân lọc máu chu kỳ nên có sự khác biệt rõ rệt.

Kết quả nghiên cứu của chúng tôi không thấy liên quan giữa tăng huyết áp và rối loạn nhịp chung của bệnh nhân trong nghiên cứu. Kết quả nghiên cứu của Hoàng Viết Thắng cho thây huyết áp tâm thu trung bình ở nhóm rối loạn nhịp là $164,5 \pm 15,6 \mathrm{mmHg}$ cao hơn so với nhóm khồng rối loạn nhịp $150 \pm 18 \mathrm{mmHg}$. Tuy nhiên, chúng tôi chỉ đánh giá bệnh nhân có THA hay không, chứ không đi sâu vào nghiên cứu theo mức độ THA nên kết quả còn hạn chế.

Kết quả nghiên cứu của chúng tôi cho thấy tỉ lệ rối loạn nhịp cao hơn ở nhóm bệnh nhân thiếu máu so với nhóm bệnh nhân không thiếu máu. Giải thích cho vấn đề này, nhiều tác giả đưa ra các luận điểm liên quan đến suy chức năng nội mạc do thiếu máu, hemoglobin là một chất vận chuyển và chất đệm cho oxid nitric (NO), nó điều hòa các hợp chất chuyển hóa ở mức độ mô tế bào. Rối loạn điều hòa chức năng nội mạc thứ phát do thay đổi nồng độ $\mathrm{Hb}$ trong hồng cẩu làm phát sinh các biến cố tim mạch có hại. Người ta thấy có sự tương quan nghịch giữa $\mathrm{Hb}$ và đáp ứng giãn mạch đối với acetylcholine (một hình thái của phụ thuộc nội mạc mạch máu). Điều này cho thây sự thay đổi chỉ số $\mathrm{Hb}$ phản ánh rất chặt chẽ sự thay đổi của thần kinh tự động của tim. Nghiên cứu của tác giả Nonmez (2010)cho thấy mối tương quan nghịch giữa chỉ số $\mathrm{Hb}$ và chức năng nội mạc mạch máu, hơn nữa, protein niệu có hiệu quả làm thay đổi sự tương quan này. Điều này chứng tỏ có giảm trương lực hoạt động của hể thần kinh phó giao cảm trong suy thận có thiếu máu so với chưa thiếu máu, tăng hoạt động hệ thần kinh giao cảm ở nhóm bệnh nhẩn suy thận chưa thiếu máu so với nhóm chưa suy thận.

\section{KẾT LUẬN}

Tỉ lệ rối loạn nhịp cao ở bệnh nhân lọc máu chu kỳ có liên quan đến tăng huyết áp, thiếu máu và rối loạn điện giải.

\section{TÀI LIẸU THAM KHẢO}

1. Bansal N, Hsu C-y, Go AS. Intersection of cardiovascular disease and kidney disease: atrial fibrillation. Current opinion in nephrology and hypertension. 2014;23(3):275.

2. Hoàng Việt Thắng. Nghiên cứu rối loạn nhịp tim trên điện tím liên tục 24 giờ ở bệnh nhẩn suy thận man lọc máu chu kỳ. Trường Đai học Y dược Huế. 2010.

3. Wheeler DC, London GM, Parfrey PS, et al. Effects of cinacalcet on atherosclerotic and nonatherosclerotic cardiovascular events in patients receiving hemodialysis: the EValuation Of Cinacalcet $\mathrm{HCl}$ Therapy to Lower CardioVascular Events (EVOLVE) trial. Journal of the American Heart Association. 2014;3(6):e001363.

4. Goldstein BA, Arce CM, Hlatky MA, Turakhia M, Setoguchí S, Winkelmayer WC. Trends in the incidence of atrial fibrillation in older patients initiating dialysis in the United States. Circulation. 2012;126(19):2293-2301.

5. Zimmerman D, Sood MM, Rigatto C, Holden RM, Hiremath S, Clase CM. Systematic review and meta-analysis of incidence, prevalence and outcomes of atrial fibrillation in patients on dialysis. Nephrology Dialysis Transplantation. 2012;27(10):3816-3822. 
6. Adamec Jean and Adamec Richard (2008), ECG Holter. Guide to electrocardiographic interpretation., 1st edition, Spriger Science Business Media, LLC., 233 Spring street, Newyork, NY 10013, USA.

7. Gan-Xin Yan and Peter R. Kowey (2011), Management of Cardiac Arrhythmias, second edition, Contemporary Cardiology, Ch.P. Cannon and A.M. Armani,Editor, Humana Press. , 89-122.
8. Macfarlane Peter $W$ et al. (2011) Comprehensive Electrocardiology, second edition, John Camm, ed, Vol. 3, Springer-Verlag London Limited 2011, 1513-167.

9. Prystowsky Eric $\mathbf{N}$ and Fogel Richard I (2013), Hurst 's The Heart, Thirteenth Edition, Approach to the patient with cardiac arrythmias, RA. Walsh, JC. Fang và Valentin Fuster, ed, McGraw Hill, New York, 91-96.

\section{ĐĂC ĐIỂM NHIỄM HPV NGUY CƠ CAO Ở CÁC TỔN THƯO'NG BẤT THƯờnG CỔ TỬ CUNG VÀ UNG THƯ CỔ TỬ CUNG TẠI BỆNH VIÊ̂N K}

\section{TÓM TẮT}

Với mục đích xác định tỷ lệ nhiễm HPV nguy cơ cao và đối chiếu với một số yếu tố liên quan. Tìm hiểu tỉ lệ nhiễm HPV với các biến đổi bất thường biểu mô cổ tử cung. Đối tượng nghiên cứu gồm 1450 phụ nữ tuổi $\geq 18$ tuổi đến khám phụ khoa tại bệnh viện $\mathrm{K}$. Phương pháp mô tả cắt ngang. Những phụ nữ đủ tiêu chuân sàng lọc được khám phụ khoa, lấy tế bào CTC làm xét nghiệm Papsmear, phân loại tổn thương theo Bethesda 2001, xét nghiệm PCR bằng kĩ thuật RT PCR máy coba4800. Kết quả tỉ lê nhiễm HPV ngưy cơ cao trong quần thể là $11,2 \%$, trong đó HPV type 16 chiếm $14 \%$, HPV type 18 chiếm 7.9\%, HPV 12 type khác chiếm $70.7 \%$, còn lại là các trường hợp đồng nhiễm HPV khác. Tî lệ phư nữ có kết quả tế bào cổ tứ cung bất thường là $3.9 \%$ và giải phẫu bệnh bất thường (LSIL, HSIL, carcinoma) 1.9\%. Tỉ lệ HPV cao nhất ở nhóm Carcinoma là 100\%, HSIL (92,8\%), LSIL(67\%), AGUS (67\%), ASCUS 15\%, ASC H (14,2\%)

Tư khóa: HPV, cổ tử cung, ung thư cổ tử cung

\section{SUMMARY}

CHARACTERISTICS OF WOMEN INFECTED WITH HIGH RISK HPV IN EPITHELIAL ABNORMALITIES AND CERVICAL CANCER

This study aimed at investigating HPV occurrence in comparison with cervical epithelial abnormalities and cervical cancer. Study population consisted of 1450 18-year and over women at K hospital. This was a descriptive cross sectional study. Eligible women were selected for undergoing pelvic examination and taking cervical specimen for Pap testing. The Pap results was indentified by Bethesda 2001, and HPV status was identified by PCR. Results shown that HPV positive is $11.2 \%$, among that, HPV $1614 \%$, HPV 18 $7.9 \%$, HPV 12 other type 70.7\%, cervical epithelial abnormalities and cervical cancer $3.9 \%$, histological abnormalities $1.9 \%$. The highest HPV positive rate

*Bênhh viện K cơ sở 3 Tân Triều

Chịu trách nhiệm chính: Nguyễn Thị Bích Phương

Email: phuongntb2101@gmail.com

Ngày nhận bài: 20.9.2021

Ngày phản biên khoa họ: 12.11.2021

Ngày duyệt bài: 23.11.2021

\section{yễn Tiến Quang*, Nguyễn Thị Bích Phương**}

$100 \%$ in cervical cancer, HSIL92.8\%, LSIL 67\%, AGUS $67 \%$, ASCUS 15\%, ASC-H 14,2\%.

Key word: HPV, cervical, cervical cancer.

\section{I. ĐẶT VẤN ĐỀ}

Theo Globocan 2018, ung thư cổ tử cung (UTCTC) là một trong các nguyên nhân gây tử vong thứ tư cho phụ nữ, chiếm $7.5 \%$ trong các ung thư ở nữ giới [1]. Năm 2018, Việt Nam có 4117 phu nữ mắc bênh và 2223 phu nữ tử vong vì ung thư cổ tử cung, ước tính mối ngày có 11 phụ nữ mắc mới và 07 phụ nữ tử vong vì ung thư cổ tử cung [2]. Theo Tổ chức $Y$ tế Thế giới (WHO), 99,7\% các trường hợp ung thư cô tử cung đều có liên quan đến việc nhiễm các típ nguy cơ cao Human Papillomavirus, là là loại vi rút phổ biến lây truyền qua đường tình dục [3]. Trên cơ sở đó, việc sàng lọc ung thư cổ tử cung ở nhiều nước khổng chỉ sàng lọc tế bào học cổ tử cung mà còn sàng lọc bằng phát hiện xem người phụ nữ có hay không tình trang nhiễm HPV típ nguy cơ cao. Virus xâm nhập vào biểu mô cổ tử cung tạo nên các biến đổi của tế bào và diễn tiến này kéo dài nhiều năm với biểu hiện từ tổn thương viêm nhiễm đơn giản đến tân sinh trong biểu mô, ung thư tại chố và xâm lấn. Do đó, việc phát hiện sớm bằng tế bào học, xét nghiệm HPV là cần thiết, giúp tăng khả năng phát hiện, điều trị sớm tổn thương cổ tử cung nhẳm giảm tỷ lệ tử vong của bệnh.

Chúng tôi thực hiện đề tài "Đặc điểm nhiễm HPV nguy cơ cao ở các tổn thương bất thường cổ tử cung và ung thư cổ tử cung tai bệnh viện K" với các mục tiêu: xác định tỷ lệ nhiễm HPV nguy cơ cao và đổi chiếu với một số yêu tố liên quan.

\section{II. ĐỐI TƯỚNG VÀ PHƯƠNG PHÁP NGHIÊN CỨU}

Đối tượng: 1450 phụ nữ đến khám phu khoa tại bệnh viện $K$ được xét nghiệm tế bào cổ tử cung và xét nghiệm HPV từ 12/2019 đến tháng 10/2020. 